CATALAN REVIEW

Catalan Review

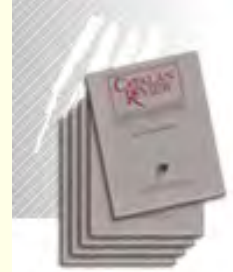

You are accessing the Digital Archive of the Catalan Review Journal.

By accessing and/or using this Digital Archive, you accept and agree to abide by the Terms and Conditions of Use available at http://www.nacs-

catalanstudies.org/catalan review.html

Catalan Review is the premier international scholarly journal devoted to all aspects of Catalan culture. By Catalan culture is understood all manifestations of intellectual and artistic life produced in the Catalan language or in the geographical areas where Catalan is spoken. Catalan Review has been in publication since 1986.
NORTH

AMERICAN

CATALAN

SOCIETY
Esteu accedint a l'Arxiu Digital del Catalan Review

A l' accedir i / o utilitzar aquest Arxiu Digital, vostè accepta i es compromet a complir els termes i condicions d'ús disponibles a http://www.nacs-

catalanstudies.org/catalan review.html

Catalan Review és la primera revista internacional dedicada a tots els aspectes de la cultura catalana. Per la cultura catalana s'entén totes les manifestacions de la vida intel lectual i artística produïda en llengua catalana o en les zones geogràfiques on es parla català. Catalan Review es publica des de 1986.

\title{
Addressing Fear and Grief: Llullian Mnemotechnics and Alchemico-Llullian Signs in Donne's Sermon(s) for the Churching of the Countess of Bridgewater Roberta Albrecht
}

Catalan Review, Vol. XX, (2006), p. 9-37 


\title{
ADDRESSING FEAR AND GRIEF: LLULLIAN MNEMOTECHNICS AND ALCHEMICO-LLULLIAN SIGNS IN DONNE'S SERMON(S) FOR THE CHURCHING OF THE COUNTESS OF BRIDGEWATER
}

\author{
ROBERTA ALBRECHT
}

\begin{abstract}
This study recontextualizes two of Donne's churching sermons according to the Llullian mnemotechnics that were so fashionable in his age. It investigates how Donne's public audience (composed of radical Calvinists, Arminians, and Roman sympathizers) and his private audience (composed of members and friends of the Bridgewater family) were predisposed to respond to his text. It employs Llull's triadic and correlative principles and Llullian concepts of grammar in order to show how many understood the signs diffused throughout the sermons. Donne provided the alchemico-Llullian signs, knowing that his congregation would match the nouns (which Llull defined as "the nature of things") with the verbs (which Llull defined as "how things exist or operate") in order to construct their own sentences. In this manner, each member of Donne's congregation was able to compose a statement of his or her own values. Three recurring signs-the ark, the rainbow, and restillustrate how Donne's pseudo-Llullian mnemotechnics work. All three translate into some version of "the title promis'd them the Land." As an olive branch, these sermons offer peace to religious and political antagonists and consolation to those who, for various reasons, seem to have lost all hope of their "Rest."
\end{abstract}

\footnotetext{
This essay falls into three parts. Section I surveys the intellectual history informing Donne's sermons. Section II discusses how Donne composed these churching sermon(s) in order to make them accessible, and therefore more acceptable, to different kinds of audiences, including those familiar with the system of spiritual logic devised by Ramon Llull (ca. 1232-1316?). Finally, section III explicates Donne's sermon(s) as the Bridgewater family, and certain millenarians, may have understood them.
} 


\section{REMEMBERING THE INTELLECTUAL HiSTORY OF EARIY MODERN ENGLAND}

The revival of interest in Llullian mnemotechnics was a pan-European preoccupation during the $198 \mathrm{os}^{1}$. Yet despite this good beginning, scholars working today have failed to grasp Lhull's profound influence upon theories of logic and rhetoric during the period when interest in ars memoria was at its apogee. Why this is so is discussed by Paolo Rossi $^{2}$ and his translator, Stephen Clucas, ${ }^{3}$ in Logic and the Art of Memory: The Quest for a Universal Language. "[I]t is a bad thing," Rossi observes, "that historians have believed (and still believe) that they can understand the controversies... of the early modern period, when they remove them from the vital historical context of these [Llullian and pseudo-Llullian] techniques"(xvi).

During the sixteenth century, Llull's ars combinatoria and the system of "logic" it served had converged with Aristotle's ars reminiscendi and Ramus's reform of it. ${ }^{4}$ Although far from a Llullist, Ramus, who thought Quintilian wrong to confuse dialectic and rhetoric, removed memory from the province of rhetoric and developed it as a

I Some representative studies include: Schmidt-Biggemann, which shows how the confluence of the Aristotelian, Ramian, and Llullian systems extended into the eighteenth century; Sturlese's Bibliografia, Censimento, which reappraises Giordano Bruno's Llullian mnemotechnics as a form of Ficinian talismanic magic; and David S. Katz's Philo-Semitism and the Readmission of the Jewos to England roo3-165s, which reviews the work of Frances Yates and Paolo Rossi, especially as they link "the magic images of occult tradition and...the art of Ramon Lull" with the distinctive prose style of the midseventeenth century (78). Americans contriburing to this body of criticism include Mark D. Johnston, The Spiritual Logic of Ramon Llull (1987), and Mary Carruthers with The Book of Memory: A Study of Memory in Medieval Culture (1993).

2 See Paolo Rossi, Logic and the Ant of Memory: The Quest for a Universal Language. Although Llull's original works are important, Rossi argues that the numerous commentaries and treatises that sustained Llull's reputation throughout the late seventeenth century are even more important to the culture of early modern England. Rossi observes that this legacy has been overlooked by such influential thinkers as Noam Chomsky, Michel Foucault, and Jacques Derrida (xxiv-xxvi).

3 See Stephen Clucas, "Translator's Introduction," Logic and the Arr of Memory. He observes that linguists and historiographers working over the past several decades have either "ignored, misunderstood or trivialized" the significance of the ars combinatoria, which flourished between the $14^{\text {th }}$ and $16^{\text {th }}$ centuries (ix).

${ }_{4}$ For the confluence of Aristotelian, Llullian, and Ramian systems of logic, rhetoric, and memory, see Schmidt-Biggemann, Topica Universalis: "Man könnte diese Mehrfachfunktion als Preis für die Synthese der drei Wissenschaftsrichtungen auffassen, als Argumentationsrest, der aus den alten aristoteliselen, lullistischen und ramistischen Wissenschaften mitgeschleppt wurde" [One could regard this multiple function as the price for the synthesis of three scientific directions, as a remainder which was dragged along from the old Aristotelian, Lullian and Ramian sciences] (171). 
component of his new logic, which consisted of invention, disposition, and memory. ${ }^{5}$ Ramus's emphasis on memory reinforced the continuing interest in Llull's spiritual logic (also, and for very different reasons, based upon memory). Although Llull's ars memoria is non-logical in that it substitutes the analogy for the syllogism, it, nevertheless, was compelling to early modern readers interested in solving difficult word puzzles.

Llull's arguments always create relationships between signs and divine principles. Mark D. Johnston explains the reason for this. Llull, he observes, belieyed that the Memory, Will, and Intellect always "perform their functions most 'nobly" when they remember, desire, and understand a Creator" (8I). Certain seventeenth-century thinkers, especially those millenarians seeking a balance between biblicism and hermeticism, were attracted to Llull because they thought that if they could teach people to investigate biblical signs (and hermetic versions of the same), they could promote unity among otherwise antagonistic religious groups. ${ }^{6}$

\section{MiLLENARIANISM AND LLULL'S LOGIC AS CONTEXT}

Among these millenarians was Johann Heinrich Alsted (1588-1638), whose apocalyptic expectations and encyclopedic knowledge produced Thesaurus chronologiae (1624), which, Howard Hotson observes, "proved one of his most popular works, not least in England and New England, where it remained a standard component of learned libraries into the eighteenth century" (29). Donne's friend, Lord Herbert of Cherbury, owned a copy (Hotson 29n9o). ${ }^{7}$ Hotson considers Joseph Mede (1586-1638), a fellow at Christ's College Cambridge, and Alsted to be the "joint founders of the Reformed millenarian tradition" (5), a tradition sustained by their common student, Jan Amos Comenius (I592I670). Although the sermon(s) we are about to study were preached before the publication of Alsted's Thesaurus, they were nevertheless composed during a time when Mede and the English Comenians at

${ }_{5}$ For discussion of Ramus's reforms, see Rossi, Pp. 98-100. Ramus thought that "the artes logicae [should be] comprised [of] both dialectic (or logic) and rbetoric" (99). He relegated "to rhetoric only elocution and action" (100).

6 See, for example, Hotson, who observes that Alsted's peculiar brand of Calvinist millenarianism and the conciliatory spirit that it expressed emerged from his study of Llull's theories, heretofore "marginalised within the universities but extremely important in considering the balance between biblicism and hermeticism" (n).

7 Herbert's copy of Thesatrus chronologiae is now in Jesus College, Oxford. 
Cambridge were disseminating Alsted's millenarianism throughout the land. ${ }^{8}$

Gregory B. Stone defines Llull's vision as one that wanted "to heal the world's cultural wounds, wanted to make the world a place marked by religious and cultural unity" (70). Manuel Duran remarks that Llull intended to accomplish this unity by means of "the language of logic, Lullian logic" (I2). To this end, Duran says, Llull developed a "symbolic logic" consisting of "logical diagrams," and even his own alphabet (18). All this was congenial to the millenarian cause, and that is why Llull's Duodecim Principia Philosophiae, which explains his proposal for a universal logic, is important.

Dr. John Dee (1527-1608) owned two copies of Llull's Duodecim Principia Philosophiae, nineteen other texts by Llull, and many more supposititious ones.' When Dee died, Sir Robert Cotton appropriated some of these for his library. ${ }^{10}$ In fact, Kevin Sharpe observes, Cotton's collection was at that time "a substitute for the national library," not only because of its size but also because he freely loaned books and manuscripts to friends-among whom was Donne (Cotton 51 ).

Donne too owned a copy of Duodecim Principia Philosophiae (Paris, I5I6). It bears his motto and signature on the title-page and has pencil markings (not necessarily his) in the margins (Keynes 271). The significance of marks in books-marginalia, underscoring, even "pointing fists" - has been observed by Sharpe and Steven N. Zwicker as "the traces of multiple hands and dissonant voices" (7). In fact, Carol Meale argues, the marginalia of such early modern readers as Gabriel Harvey and John Dee is "the only 'incontestable evidence' of reading" (qtd. in Brayman Hacket 107). The very fact that Donne owned the Principia, and signed it himself, implies his interest in Llull's spiritual "logic," which was designed to investigate manifestations of the divine throughout creation.

Sometimes Llull accomplishes this by means of triadic principles, which diffuse throughout the world the nine Relative Principia-Power, Glory, Eternity, Wisdom, Goodness, Greatness, Truth, Will, and Virtue.

8 On Mede, see Hotson, pp. 4-14. He observes that "Mede and Alsted...make a natural pair" (5).

9 For Dee's collection of works by Llull and by pseudo-Llullists, see Roberts and Watson, p. 220. The list of original works includes: Opera, Arbor scientiae, Ars brevis, Ars demonstrativa, Ars inventiva, Ars magna, Codicillus, De regionibus sanitatis et infirmitatis, Dialectica, In rbetoricen isagoge, Janua artis Lulli, Liber principiorum medicinae, Liber proverbiorum, Mercuriorum Liber, Metaphysica nova, Practica compendiosa artis, and Testamentum.

to See Kevin Sharpe, Sir Robert Cotton. Sharpe includes Dee among those represented in Cotton's library (56). For an explanation of how "John Dee's library came to Sir Robert only indirectly," see pp. 6o-6t. 
These triads may take several forms-Differentia, Concordantia, and Contrarietas; Principia, Medium, and Finis; and Maioritas, Aequalitas, and Minoritas. We shall have occasion below to see how Donne implements the triadic beginning, middle, and end in his sermon(s).

Sometimes, Johnston remarks, Llull "redefines predication and the construction of propositions to correspond to the combinatory mechanics of his $A r t^{\prime \prime}(74)$. These include apparent contradictionsaffirmation and negation, antecedence and consequence, and possibility and impossibility. We shall study below how Donne uses these "contradictions" to dispel fear and inspire hope.

\section{PSEudo-Lluluist Hermeticism as ConTeXT}

Before confronting Donne's sermon(s), we must try to understand how alchemy squares with Llull's spiritual logic. Those who want more information should consult Frances Yates, The Art of Memory (1966), David S. Katz, Philo-Semitism and the Readmission of the Jews to England, I603-1655 (1982), or Rossi. Here I make a few preliminary observations.

Pico della Mirandola (1463-94) was the first to marry hermeticism with the cabala. Pico may have been introduced to Llull by Lorenzo de'Medici. ${ }^{\text {II }}$ Whatever his sources, Pico (and others), Rossi observes, "disseminated and commented on the works of Llull dealing with the ars magna and combinatoria, and initiated what was to become an intellectual obsession in European culture" (29). ${ }^{12}$ In fact, Pico's own ars combinandi seems to have developed as a version of Llull's ars combinatoria. Moreover, Pico seems to have been the first to attach hermetic signs to the divine names. Johannes Reuchlin (1455-1522) was so intrigued that in I 490 he went to Italy to meet Pico and study Christian cabala.

Donne's admiration of Pico and Reuchlin is a matter of record. In the Essays he praises the "Cabalists...which are the Anatomists of words, and have a Theological Alchimy to draw soveraigne tinctures and spirits from plain and grosse literall matter" (48). The phrase, "Theological Alchimy," John S. Chamberlin points out, alludes to "devices of occultist interpretation" devised by Pico and Reuchlin (Ios). Donne's overt use of theological alchemy in the sermon(s) is proof

Ir See Michela Pereira, p. 29n38. She notes that Pier Leoni, physician to Lorenzo de' Medici, owned a copy of the pseudo-Llullian manuscript, Liber de secretis naturae.

12 Others (besides Pico) disseminating Llull's ars cambinatoria included Nicolaus Cusanus, Lefère d'Etaples, (and later) Bernardo Lavinheta, Henrícus Cornelius Agrippa, and Giordano Bruno. 
that he expected his congregation to understand such references. When they heard, "[I]t is not enough to come to a calcination, or a liquifaction of the metall, (that must be done) nor to an Ablution, to sever drosse from pure," they were required to transfer their knowledge of alchemy to their respective theologies (Sermons 5: 3I I ). In the sermon(s) below, as we shall see, they were also required to transfer biblical and potentially hermetic signs-the ark, the rainbow, and rest-to their fears and expectations during the crucial years between 1603 and 1623 .

\section{The International Sign-Language Project}

While Joseph Mede was expounding his version of Calvinist millenarianism at Cambridge, others-Samuel Hartlib, Francis Bacon, John Wilkins, ${ }^{13}$ Elias Ashmole, John Dury, and William Bedel (or Bedell)were devising what they hoped would be a new philosophical language that would promote Protestant unity. Bedel's mission, Rossi says, was "Lutheran-Calvinist reconciliation in England" (Rossi 154). Because Bedel saw "the disagreement between the sects as verbal in character," he thought that the gap might be bridged by a language based upon universal characters (155).

This same conciliatory spirit prompted Bedel and Hartlib (a disciple of Comenius) to support Dury's planned visit to the Continent, where, Norman Vance says, Dury hoped to be "a kind of roving ambassador for European Protestant Unity" (30). ${ }^{24}$ This goal reflects Alsted's vision of a Church "purged, purified, and cleansed...[for] the onset of the millennium." (qtd. in Hotson 14 ).

Vance observes that Bedel, onetime chaplain to Sir Henry Wotton (Donne's life-long friend) ${ }^{15}$ was attracted to the German linguists who wished to devise an artificial language resembling "Raymond Lull's systematizing of all knowledge in terms of a universal symbolized set of divine attributes" (29). Among these Germans was, of course, Alsted, whose Thesaurus sought to reduce the whole of history to circular form (similar to Llull's revolving devices meant to combine

13. John Wilkins published Mereury, the first English textbook on cryptography in ${ }_{1641}$, after the ideas of Alsted and Comenius had begun to make some impact in England. His Essay Towards a Real Character was not published until 1668. Rossi cites Wilkins' belief that "the philosophical language would (once it had been perfected and freed from all ambiguity) clarify the nature of religious differences, and reveal them to be inconsistent" (155).

14 The Thirty Years War began in 1618 .

is Bedel was Wotton's chaplain in Venice from 1607 to IGIo. 
related concepts) and also to synthesize biblical and hermetic ingredients as a way to restore the world to perfect health (in the Paracelsean sense of wholeness).

Elias Ashmole seems to have been attracted to Alsted's hermeticism as a way to achieve Christian unity through language reform. Ashmole's decision to base the new language upon alchemical symbols - "signs for the planets, metals, minerals" - is compatible with Alsted's own hermetically-based aspirations (Katz 47). Both embraced alchemy, a pseudo-science that demands unity throughout all creation, as the proper vehicle to express their essential optimism (far beyond the predestinarian fatalism of radical Calvinists).

In order to express the essential optimism of his conditional predestinarian views, Alsted devised a system of alchemical signs (studying manifestations of the four elements throughout creation), ${ }^{16}$ analogous to Llull's nouns, or "things that are" (Johnston 75). Alsted showed how these things function as Llull's verbs, or things "existing and operating" (75); he refashioned Llull's ars combinatoria to create a version of that universal combinatorial machine that represented Alsted's own apocalyptic expectations.

Although, as I noted earlier, Donne's sermon(s) were preached before the Thesaurus was published, other works by Alsted were available to him, including a seven-volume survey of theology published between 1614 and 1622. To what extent Donne was aware of Alsted's hermetically based millenarianism, and was interested in the international sign-language project, are unanswerable questions, although his sermons for the churching of Frances Egerton do offer some clues.

\section{DONNE’S CHurching SERMon(S): AUdience}

The churching in early modern England, especially from the woman's point of view, was a time to celebrate rest after great strife. ${ }^{77}$ These two churching sermons belong to a single occasion, the birth of an Egerton son. ${ }^{18}$ They were composed (and at least one of them preached) either

16 For an example of this see, "Speculum mundi" from the Thesaurus chronologiae, reproduced by Hotson, p. 28.

17 For discussion of churchings, see Jeffrey Johnson, pp. 98-104. He observes, "There is little doubt that the service for the churching of women, a practice carried over from the medieval church, was derived from the Old Testament laws of purification for women after childbirth" (99).

18 The editors of Donne's sermons say, "it seems likely that it [this sermon] was preached after the birth of an heir, for most of the children were daughters" (The 
in 1621 or in $1623 .{ }^{19}$ Both dates concur with what Rossi calls the "apogee" of the "upsurge of interest in the techniques of the ars memoria" (64), which was also a time of intense political and religious strife in England.

Potter and Simpson do not think that Donne preached "the first two sections, which are full of threatening and warning....very unsuitable for the churching of any lady" (Sermons 5:13-14). For reasons about to be explained, I disagree. We do have evidence that some among Donne's audience, including Frances Egerton, ${ }^{20}$ were attentive listeners and readers. Moreover, those who were able to recognize the hermetic counterparts of Donne's "warnings" could understand them as signs of comfort. Certainly Frances Egerton's uncle, William Stanley, (providing he attended) would have been one of these. ${ }^{2 I}$

Donne preached the churching sermon at the Bridgewater house in London. If this event occurred in 1621, then possibly Prince Charles and the Marquis of Buckingham attended. A letter from John Chamberlain reports that both attended the christening of the Earl of Bridgewater's son in that year, ${ }^{22}$ so it does not seem unreasonable to believe that they may have also attended this churching. Lord Herbert of Cherbury, whose son, John, married the Earl's daughter, Lady Mary, in 1627, may also have been present. Later earning "his reputation as the first English

Sermons 14). For a different view, see N. L Matar. He states that the Countess of Bridgewater had given birth to a daughter in 1623 : "Although the records they [the editors] examined showed that in both June 1621 and June 1623, the Countess had borne respectively a son and a daughter, the editors were unable to confirm precisely the date of the sermon" (447). In fact, the editors cite John Chamberlain, who reported on 19 April, 5623, "that the Earl's 'only sonne died yesterday, but there is hope left seeing his lady is with child, and redy to lie down," and two months later, on June 14, he reported that a son [emphasis mine] had been born" (14).

19 The editors date them "? I62i or $1623 . "$

20 Keyes provides evidence that Frances Egerton "appropriated" Donne's sermons as her own as "she has pur her initials, F.B., on the fly-leaf and title-page of the sermon on Judges $v .20^{\text {n }}$ (Keynes 28). Potter and Simpson reaffirm this and more, saying, "On the flyleaf of the Sermon on Judges 5.20, and also on the title page, are (written in ink) the initials 'FB' four times repeated.... 'FB' are presumably the initials of Frances, wife of John the first Earl of Bridgewater," ("Introductions," Sermons i: 13 ).

21 William Stanley (baptized 1561 , d. 1642) became the $6^{\text {th }}$ Earl of Derby after the death of his elder brother, Ferdinando, leaving Frances Egerton's mother, Lady Alice Spencer Stanley, a widow until she married Sir Thomas Egerton (1540?-1617), Lord Keeper of the Great Seal (then Donne's employer) in 1600 . For discussion of his interest in alchemy, see Dennis Flynn, p.41. Flynn bases his remarks partly upon a reference from Gcorge Chapman. In a prefatory letter to "Poeticall Hymnes" Chapman mentions the "ingenious Darbie" as one member of "the School of the Night, a group of students of alchemy and allied disciplines" (qtd. in Flynn 41).

22 See Sermons, p. 14. The editors cire a letter by Johin Chamberlain (2 June, 1621). 
deist, "Joseph H. Summers observes, Lord Herbert was unorthodox to the extent that he "had no strong objections to the Church of Rome" (33). This would suggest Lord Herbert's capacity to understand Donne's alchemico-Llullian signs as allusions to Roman doctrine.

The Bridgewaters themselves, according to William Riley Parker, "were a religious family, and there is some evidence of Puritan leanings" (2: 792). He cites John Collinges, who notes that Frances Egerton's eldest daughter, Frances, "had a Huguenot governess when a child" and "learned "to be a Calvinist in point of Doctrine, and a Presbyterian as to Discipline" (2: 792). Her younger sister, Katherine, he adds, "worried about mis-spending 'part of many Lord's days in masques and other court pastimes'" (2: 792). Katherine was either ten or twelve when these sermons were preached. Perhaps she attended this churching. Other members of the Egerton family-nephews, nieces, and cousins - may have attended ${ }^{23}$ So, supposing that all of these "supposes" are true-that William Stanley, Katherine Egerton, Prince Charles, the Marquis of Buckingham, Edward Herbert, all attended this churching - then we must conclude that various interests and sensibilities were represented.

Potter and Simpson think that the first sermon was originally a mere "few paragraphs," which Donne later expanded and developed for publication (Sermons 5:14). In fact, the editors think that only the second sermon, which makes specific reference to the lady, was actually preached. I have two responses to this. First of all, my interpretation of the first sermon is such that it coheres very well with the second. What version was actually preached we cannot know, but, on the basis of internal evidence, there is reason to believe that it was a compilation of what was later published as two sermons. Second, Donne was keenly aware of future audiences, and he designed his texts to reach future readers.

N. I. Matar examines the moment this churching represents; he concludes that it "shows Donne reiterating current ecclesiastical policy and discrediting the Jewish millenarianism that other Anglicans had denounced in that year [162I] and that had been deemed by James I to be dangerous to his authority" (448). Matar fixes upon one particular incident involving one particularly imprudent millenarian (a matter to be discussed in some detail below). I cannot agree that Donne was joining "other Anglicans" by "discrediting" all millenarians, but I do agree that the sermon(s) were probably preached as a more coherent whole than Potter and Simpson would have us believe.

${ }_{23}$ See Parker, pp. 758-59 and 790-91. He lists Frances Egerton's relatives, some of whom might have attended this churching. These include cousins, for example, Elizabeth Carey (d. 1635); uncles, for example, William Spencer (d. 1624); brothers-in-law, for example, Henry Hastings, $5^{\text {th }}$ Earl of Huntingdon (d. 1645), who married Lady Elizabeth in 1603. 


\section{Llullian Principles as Structure For DONNE'S SERMONS}

Donne's sermon(s) address the concerns of religious and political opponents and, at the same time, the fears and grief of the Bridgewater family. "Sermon 9 " and "Sermon ro" fall into three parts-which Donne defines as warning ("Commination"), instruction ("Commonition"), and consolation. This seems to indicate a step-by-step process towards some clear goal. But, in terms of Llull's Relative Principia, these stages represent different manifestations of the same single act. Whether we study the end or the middle, all will lead to the same "divine" place. Llull's several triadic constructions, Johnston observes, "impose a trinitarian image on every created being" (19). As we investigate the three parts of Donne's sermon, we do well to understand that Consolation is inextricably bound with Commination, as is Commonition with Commination, and so forth. So while I study mainly Donne's Consolation-implied by the signs of the ark, the rainbow, and restthese distinctions necessarily break down, so that "warning" and "instruction" are manifestations of the same act.

We begin with the sermon text: "Arise and Depart, for this is not your rest" (Micah 2:Io). Donne defines rest as the antithesis of "labour and fear" (208-9). This way of defining by negatives, that is, what constitutes "not" rest, is very Llull-like in that it means to discover truth by affirmation and negation (both will lead to the same). ${ }^{24}$ It may be significant that Donne confines the noun "unrest" to the first part (or what is called "Sermon 9"), where it is repeated in various forms: "A false ascending" (189), "false joy and false ease" (190), "none of his rest" (193), "imaginary rest" (193), etc.

Hence Donne's method of studying rest resembles Llull's spiritual logic in that it investigates identity (joy/ease/ascending) and difference (false joy/false easel descending). Also, like Llull, he begins by discovering the "nouns," what things are (Johnston 75). Once the nature of these things-rest, ark, rainbow-is understood, then the principles by which all things exist and operate, or the verbs, can be determined.25 This is how Donne's congregation will make sense, rather sentences, of the text themselves.

Donne says, "God took in Noah's sacrifice, after he came out of the Ark...[and]The Lord smelt a savor of Rest" (193). Now you can rest, he adds, in "the Arke of thy strength," and in that "Rest" which is "the

24 For ways that Llull constructs propositions corresponding to the divine, see Johnston, p+ 74.

${ }_{25}$ For another way of explaining this Llullian principle, see Albrecht, pp. 102-103. Donne's pseudo-Llullian mnemotechnics compel his readers "to compose sentences using linking verbs like is and seems in order that they might articulate 'something like something else but not the same'" (103). 
Arke" (213), Attached to the ark is the rainbow, a sign of the Covenant. But the readers' task is to determine "which" ark, "which rainbow," even "which flood." Once they discover the nature of these nouns, they can determine what verbs to attach, whether is, which anchors the noun in the declarative mode, or seems, which invites questions.

As signs, ark and rainbow may be read as either Israel's "Jerusalem" or as the Christian's "Rest." Early modern readers understood the ark and the rainbow to be references to that moment recorded in the Bible when, after the Flood, God set His "bow in the cloud...as a token of a covenant...that the waters shall no more become a flood to destroy all flesh" (Gen. 9: 13-I5). As an anti-type of this type, the miracle of Christ walking the waves proves Him to be the Ark that will keep souls safe from drowning.

Many, however, would have understood the alchemical sense of ark and rainbow, even as Donne uses these in the Devotions to convey the shape-of "half a circle"-which is "the great seal to all the world...that secured the world for ever from drowning" (129). This same seal had its counterpart in that "hermetic seal which closes the alchemical vessel and keeps it airtight" (Abraham 99). So Donne could expect his audience to recognize the shapes (the circle/half-circle) and the protecting hermetic seal.

The fact that Donne employs covert alchemico-Llullian references implies that he expects his congregation to understand this level of discourse as well. Some examples are these: "established" (185), ${ }^{26}$ "not salted" (186), ${ }^{27}$ "in massa damnata, a loafe of Adams dow" (186), ${ }^{28}$ "prison" (190), ${ }^{29}$ "Iron fornace" (190), ${ }^{30}$ "iterated and multiplied"

26 See, for example, Albrecht, p, 229. Fixionem (or establishment) is "[t]he final stage of the opus when purified matter, the nature of which is volatile or 'fugitive,' is stabilized" (229). See also Mazzeo, "Notes on John Donne's Alchemical Imagery." He observes, "Although sublimation was the most important alchemical process, it is interesting to observe that, for Donne, the most important process was fixation" (II4).

27 Sec Abraham, Dictionary, p. 177: "In traditional alchemical theory salt, like ash, is a synonym for the pure white stage or albedo."

28 See Abraham, p. 3: "In the context of the opus alchymicum Adam is a synonym for the prima materia, the substance from which it was believed the universe and all things in it were created....The necessity for the chemical wedding (or coniunctio) was based on the idea that after the Fall man lost his original, undivided Adamic state and had to strive to reconcile and unite conflicting halves of his self to regain his integrated nature." Sce also, "paste" (or dough). "The coniunctio or chemical wedding of the Stone's soul with its purified body during fermentation is often compared to the making of bread," (140).

29 See Abraham, p.156: "The stage of the opus known as putrefaction and nigredo; the name of the vessel during this stage."

30 See Abraham, p. 82. "By undergoing the fire of the furnace the metal (or soul of 
(I9I), 35 "putrefied" (203), "digested, and then perfected" (206), 32 "settles and establishes" (207), "Sanctum Sanctorum" (209), "dissolves" (2II), ${ }^{34}$ "putrefaction" (2II), and "reuniting the body and soul" (2I3). ${ }^{35}$ Although we moderns may not see these references as alchemical, many among Donne's congregation did.

Of course, some of these signs represent stages in a process, including Llull's triadic schema-Principia, Medium, and Finis. Hence "in massa damnata" and "putrefied" relate to the divine (the end) by anticipation. So while "damnata" may seem to elicit fear, even terror, Llullists understand this sign as a necessary stage towards perfection. Indeed, Llull's theory of coessentiality demands both evil and good, beginning and end, minority and majority, impossibility and possibility, antecedence and consequence-all, in their own way, become manifestations of the same divine end, and all square well with Alsted's vision of a Church "purified, and cleansed."

Some interested in the international language project might understand Donne's reference to "Adams dow" as a sign of those names Adam gave to God's creatures - names now lost. David S. Katz reminds us that " $[\mathrm{m}]$ ost scholars believed that the names which Adam gave to the creatures expressed in some way their essential natures, so that naming was equivalent to knowing" (50). Certainly Donne testifies that, "names are to instruct us, and express natures and essences. This Adam was able to do" (Essays 23). So millenarians reading "Adams dow" might naturally connect it with "perfected" and "established," expressing something like Alsted's hermetically-based apocalyptic expectations.

man) experiences suffering and mortification yet at the same time is cleansed of its impurities and corruption."

3r See Abraham, p. 132. She cites The Secret Book of Artephius: "Artephius advised the alchemist to take the red elixir and reiterate the operation of dissolution and coagulation: "Thus also is the virtue thereof increased and multiplied'" (132).

32 See Abraham, p. 55; digestion is "the refinement or maturation of an uncooked substance by a gentle heat.... Ripley also used the term 'digestion' when describing the process of bringing the matter to the stage of the albedo, and then to the rubedo: 'And so our Stone by Drynes and by Hete,/Dygested ys to Whyte and Red complete."

33 See Eluned Crawshaw, pp. 324-48. "The notion of correspondence gave a symbolic force to alchemical operations since the metals might represent the alchemist and the degree of purity they reached would consequently indicate the adept's own level of spiritual attainment....the adept had already to be in state of grace if he were to achieve anything in the laboratory" (332-33).

34 See Abraham, p. 146: "The alchemists also stated that the Stone, like a man, is composed of body, soul and spirit. The body has the power to fix or coagulate the spirit. The spirit has the power to dissolve and penetrate the body."

35 See Abraham, pp. 146-147. The alchemists also stated that ....[T] power to re-animate the body and unite the body and spirit in perfect harmony. 
We have evidence, at any rate, that Donne's congregation was able to accept the inherent analogies between the alchemical ark and alchemical rest and their theological counterparts. For one thing, Gareth Roberts observes, "[a]lchemical discourse was...suffused with the language of Christianity, its ethics, scriptures, liturgy and doctrines" (78). As early as the eighth century, for example, alchemists were comparing "the transformation of metals...to the transformation of the soul," and later they "thought of metals being redeemed from their sins" (Roberts 78).

This suggests that many among Donne's adept congregation understood the rainbow as "rest" in the sense of alchemical "fixing," or fixionem, distinguishing the wet from the dry. So when he links "remorsefull tears" with "moist Clouds" (202), these knew to anticipate the alchemical rainbow, which Stanton J. Linden calls Cauda Pavonis, "in alchemical symbolism, the colors of the rainbow that mark a late stage in preparing the opus" (Mirror 130 ). One emblem from Stolcius' Viridarium chymicum (Frankfurt, 1624) may serve to illustrate.

Stolcius' treatise depicts the moist Mercury Queen with the dry Sulphur King standing beneath a rainbow. The ark is naturally connected with the rainbow in alchemical theory, for it is the name of the secret

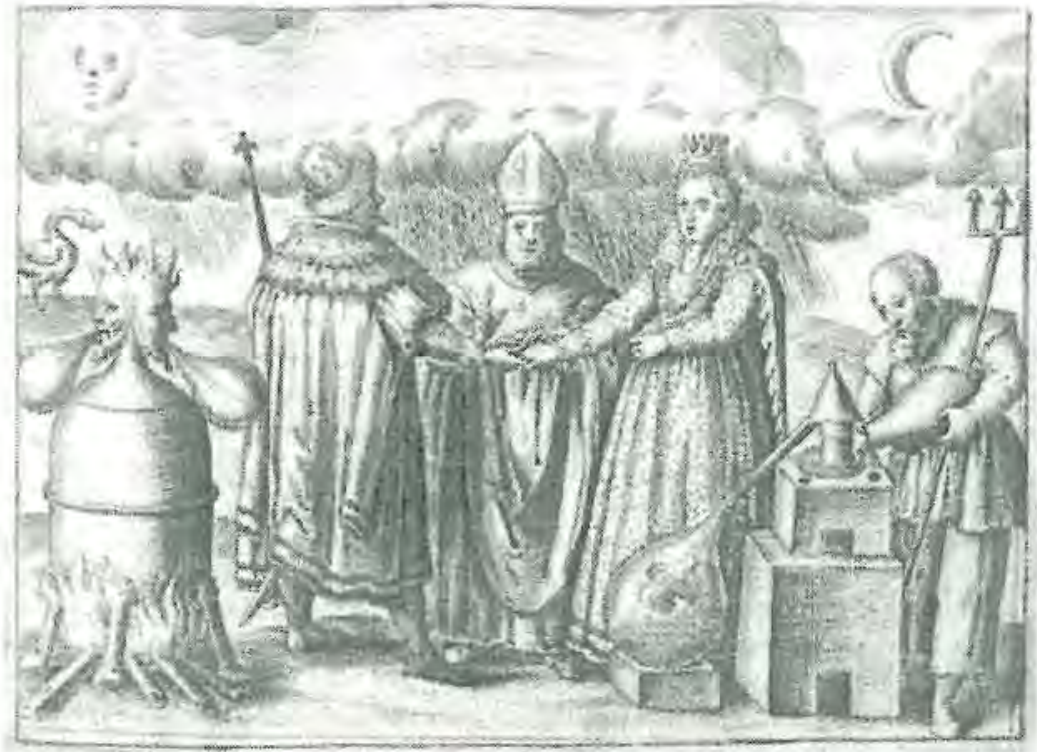

Figure r: Mercury Queen and Sulphur King with Rainbow. From Stolcius VON STOLCENBERG, VIRIDARUM CHYMICUM (FRANKFURT, 1624). UNIVERSITAT BIBLIOTHEK MANNHEIM. 
vessel, where the generation of the Stone occurs. Although the alchemical flood is dangerous, the ark will assure safe delivery of the alchemical child.

We shall see Donne employ such signs as these, inviting warring political and religious factions to discover therein their own particular dove of peace, offering them, as it were, an olive branch. Hence the barriers dividing hyper-Calvinists from Arminians, dividing parties opposing Buckingham from those supporting him, ${ }^{36}$ are-at least momentarily-broken down. Before further examining the mnemotechnics in these sermons, let us review the religious and political context.

\section{Politics AND ReLigion as CONTEXT}

When these sermons were preached, William Laud was merely Dean of Gloucester. But later, David Cressy warns us, under Archbishop Laud, churchings became traps or "tests of conformity" to Anglicanism (i1). ${ }^{37}$ The extent of Donne's prescience we cannot know. We only see that he has designed these sermons so that bitterly opposed camps can be satisfied by the same thing. Some, for example, were worried about the proposed Spanish match, and the impact it would have upon England. To such as these, Donne's references to "the Arke" and to "Rest" offer hope that England will survive this political storm.

Were these sermons preached in 1621 , then James I would have been dealing with a crisis at home. In March of that year, the king's sergeant-at-law (and a radical Calvinist millenarian), Sir Henry Finch, published a treatise, The Calling of the Iewes. This treatise argued that Israel's rest or New Jerusalem, once established, would require all monarchs of the world to bow before a governor elected by the Jews. ${ }^{38}$ The king expressed his displeasure by committing Finch to the Fleet "without trial" (Prest $\mathrm{I}_{4}$ ). ${ }^{39}$ Later that same year, on June 19, when

36 For the developing relationship between Buckingham and the Earl of Arundel, see Kevin Sharpe, "The Earl of Arundel, His Circle and the Opposition to the Duke of Buckingham, 1618-1628." Buckingham wished to keep tight reins on the earl, and Arundel wished to see the Howards restored to full power.

37 William Laud did not become Arehbishop of Canterbury until 1633. The progress of his career, however, can be traced from 1611 , when he became president of St. John's College (Oxford) and 1616, when he became Dean of Gloucester.

38 See Prest, p. 108; Finch insisted, he remarks, that "when the church of the Jews becomes the catholic church of all the world," all administrations will be revised and restructured to accommodate that.

39 See Knighton, p. 236: "On 3 June the king was persuaded (by Buckingham) to give Laud (then dean of Gloucester) a hint of further promotion. On 19 June (1621)... Laud 
William Laud preached the king's birthday sermon, he publicly attacked Finch (Ii4). Years later, Anthony Milton observes, Archbishop Laud could afford to be more discreet, hiring underlings like Peter Heylyn to act as his "clerical rottweiler[s]" to snarl at Puritans ("Canon Fire" 231).

Were these sermons preached in 1623 , then they would have followed the departure of Prince Charles (earlier that year in March) for Spain. Armed with the Duke of Buckingham and a somewhat hastily compiled Spanish translation of the Book of Common Prayer, ${ }^{40}$ Charles hoped to win the Infanta as his bride. Moderates generally approved, but Calvinists of the radical sort decried a match that threatened England's "Rest."

Whatever the date, we can assume that Donne was aware of such rising tensions when he composed this/these sermon(s). We can also assume that he knew what methods his audience might employ in order to understand the text. Some of these ways have been suggested by John T. Shawcross, Huston Diehl, Kevin Sharpe, and Stephen N. Zwicker. Shawcross stresses the importance of the reader's experience during the act of reading. He designates the reader's text as "the understanding the reader derives from reading" (4). Diehl observes that early modern readers "enjoyed the pleasure of interpreting the obscure, the enigmatic, and the esoteric" (73). Sharpe and Zwicker observe that Protestant humanism encouraged early modern readers "to compare and conflate, to discern and apply meaning" (5).

What no one has noticed, however, is the way that Llull's ars combinatoria (and pseudo-Llullian versions of it) had already predisposed Donne's readers to make meaning of the text. The Relative Principia and other correlative principles Llull devised are the means whereby readers discover "congruence with God" (Johnston 24). They help readers discover the nature of things, "what they are" (Minoritas or agent or consequence), which are the nouns in Llull's grammar. Once readers have discovered the nouns, they can begin to implement constructions of propositions-such as possibility and impossibility, and antecedence and consequence-in order to find how these things are "existing" or "operating" (75). These are the verbs in Llull's grammar. Once they have determined the nouns and the verbs, the text becomes their own.

Donne himself "thinks" this way in this sermon. His purpose

preached at Wanstead where the court was keeping the king's birthday. Four days later it was being said that Laud would be made dean of Westminster."

40 See Knighton, p. 247. John Williams, Dean of Westminster, hearing of Spain's reluctance to deal with an "English church [that] had no formal liturgy .....arranged for a renegade Dominican, Fray Fernando de Teleda, to translate Cranmer into Spanish, and forwarded the result to Madrid with King James's approval" (247). 
throughout has been to investigate the nature or essence of rest, and his thoughts are anchored in the Aeternitas of the Principia when he announces, "This rest is not then in these things [sleep, "presumption of grace," "false joy," etc.]...not in their nature; for they are fluid, and transitory, and moveable, and these are not attributes of rest" (208209). Having distinguished the "not-noun," he proceeds to the "notverb," announcing that this rest is "not in their use; for they are got with labor, and held with feare; and these, labour and feare, admit no rest" (208-209).

This sense of "not-rest" extends to the hyper-Calvinist doctrine of particular grace. Donne warns, "We have seen men infinitely prodigall grow infinitely Covetous at last. For the other way, (the assistance of particular grace) that we must not presume upon; for, he that opens himselfe to tentation, upon presumption of grace to preserve him, forfaits by that, even that grace, which he had" (204-205). This manner of direct attack is merely occasional as Donne prefers to allow his congregation to determine their own meanings, affirming and negating as they will.

Certain Calvinists, for example, predisposed to read rest as "alchemical "election" (Roberts 79), can supply the operating verb to references like "why God elected some" (206) or "their irrecoverable exclusion" (188), constructing sentences that affirm their own doctrines. ${ }^{41}$ These will see rest as that salvation inherent in God's Wisdom, that is, His foreknowledge when He decreed the elect, so that predestination becomes God's wisdom operating until the elect are glorified.

Gareth Roberts has remarked the way Calvinists developed their own kind of theological alchemy, including "a notion of alchemical 'election'... 'God maketh it sensible,/To some Elect, to others he doth it denay.' (Ashmole qtd. in Roberts 79). Likewise, Roberts observes, these Calvinist adepts believed that "an alchemical treatise may claim to be perfectly lucid to those predestined to understand it ("dignis \& Deo praedestinatis')."42

So as Calvinists combined rest in Donne's sermon with election and grace, they discover fixionem - "till we be fix'd" (214); "settles, and establishes" (207), or perfection of the Stone- "graven with an Iron pen in...stone, for ever" (2.12). Hence they are reminded of what they already know, that the elect can rest in the arms of a sovereign God who has chosen them before the foundation of the world. Likewise,

$4 \mathrm{I}$ For discussion of the Calvinist view of "alchemical" election, see Gareth Roberts: "There is a notion of an alchemical 'election' just as there is a religious one, especially in Calvinism: 'God maketh it sensible,/To some Elect, to others he doth it denay', and an alchemical treatise may claim to be perfectly lucid to those predestined to understand it.... The Stone is found by the few that have retired from society" (79).

42 Roberts is citing Aureus tractutus in Musaeum Hermeticum. 
because Calvinists understand "basenesse" (189) and "putrefied" (203) as nouns expressing total depravity, they are able to construct sentences declaring the necessity that God do all in the work of salvation.

Arminians, on the other hand, reading the same signs, discover another doctrine. Because to them "in massa damnata" or "Adams dow" (186) are "nouns" expressing the divine nature of prima materia, they are able to construct sentences declaring the anticipation of God's finished opus, which is indeed rest. These have discovered God's justice, which Llull, Anthony Bonner notes, always considered alongside wisdom when he discussed predestination: "Llull always discusses predestination and free will in terms of wisdom and justice, in the sense that God's wisdom would be imperfect without predestination and His justice imperfect without free will" (Selected Works 36in42). The perfection of justice, Llull believed, demands the perfection of wisdom, and that is because these divine attributes (wisdom and justice) are coessential.

So free will and predestination, which seem to be contraries, are actually concordant. Llull expressed his resolution to this intellectual dilemma by distinguishing between eternity (the divine attribute of Eternitas) and finitude. That is how he concludes that "Predestination, in God's wisdom, is idea; in creation, however, it is creature" (620). Likewise, "Mercy, in eternity, is idea; in something predestined, however, it is creature" (620). Nevertheless, during the seventeenth century predestination proved to be a divisive doctrine because, as we have shown, some insisted upon emphasizing one part of Llull's equation (wisdom) over the other (free will).

\section{In massa damnatalAdams dow}

divine in all creation $\wedge$ original sin $\wedge$ rotten root $\wedge$ original godliness

Women's Work/Ablution Total Depravity $\wedge \wedge \wedge$

Adepts Radical Calvinists

Arminians 
Donne's sermon is designed so that Arminians can combine "in massa damnata" with certain other phrases suggesting operating principles (or verbs) - "perpetuall motion" (193), "iterated, and multiplied" (I9I) - to conclude that they too must do the work. Because they are not totally depraved, because the divine does reside in them even in their fallen state, they take Donne's references to "an ability, to performe the conditions" (197) and the ability "to rise" (204) as affirmation that works will lead them "home" ("our rest is at home," 209). One might say that, in terms of Llull's logic, Arminians were more aware of the creature's role in the process of salvation, leaving the "idea" to God.

\section{TRACKING DOWN REST}

This last section investigates Donne's sermon text, "Arise and depart, for this is not your rest," in terms of Llull's triadic Relative Principia (Principium, Medium, and Finis). Although rest is the goal (Finis), it cannot be attained by the creature except in relation to divine love, which Llull insists "is not in accord with beginning, middle, or end.... [for] divine love has no beginning, middle, or end" (182-83). It may be significant that Donne's first sentence includes both love ("that we love him with all our beart") and rest ("rest, round about us"). Somehow the two must cohere. Because Llull's sign for divine love is the red triangle (Selected Works i82n34), and because the alchemical sign for rest is red, ${ }^{43}$ we should try to understand how some among Donne's congregation combined these "reds" in order to make meaning of the text.

"[T] Covenant of salt," Donne says, is the sign of this future rest. This is a reference to God's covenant with Israel (Numbers 18: 19), "it is a covenant of salt forever." But salt is also the alchemical sign for the body that must be combined with its contrary, spirit. When body and soul unite, purified matter is at rest. Rest is by far the most frequently repeated alchemico-Llullian sign in these sermons, but it cannot be understood apart from the signs attached to it.

One such sign is "covenant," which is attached to another, the ark. The ark, in turn, assumes three other forms. One is the Ark of the Covenant (placed in the tabernacle, moved from Jordan to Jericho to

${ }_{43}$ See Kelly, who writes, "Xiphilinus and the rest of the philosophers agree in this, that the white colour must precede the red," r43. Also see "Calid's Secret of Secrets" in The Mirror of Alchemy, edited by Linden (above). "Wherefore the Philosopher's call it [green] their Bud, and their Water of Purification, or Putrefaction; and they say truth herein; for with its water it is putrefied, and purified, and washed from its blackness, and made White. And afterwards it is made the highest Red," III. 
Beth-el, captured and returned, and, finally, placed in the tabernacle in Jerusalem). Another form of the ark, as sign, is the rainbow that appeared after the Flood. It represents God's covenant never again to destroy "all flesh" by water (Genesis 9: 13). A third version is the alchemico-Llullian rainbow in the Sage's vessel, when all the colors appear. This "ark" represents a promise that the Stone will be born.

These arks, these rainbows, and these covenants assume various forms in Donne's sermons. Although Donne never mentions rainbow per se, it is naturally attached to such signs as these: "promise" (I86, I88, 195, 196), Ark (193, 207, 213), Messias (188), peace $(193,206,208)$, "Jerusalem" (215), "booke of life/Names" (188), Sabbath (193, 207), "Sanctum Sanctorum" (209, "possession" (194), "stone" (212), Resurrection (198, 209, 2II, 2I2), "eternall glory" (203), and "home" (209).

All of these signs are references to the promise of "the title" and the actual possessing it. For the Bridgewater family this "title" was very important.

John Egerton was created First Earl of Bridgewater two months after his farher's death in 1617. Apparently Buckingham "extorted" $£_{20}, 000$ in exchange for the Bridgewater title (DNB). This price being so dear, the new earl may have thought of his "title" or "Rest" as a thing too great to lose. A brief survey of the family history shows how the earl and countess were prepared to read all of Donne's references to rest, ark, and rainbow.

\section{BRIDGEWATER FAMILY HISTORY}

Frances Egerton's first two sons had died sometime before 1615. A third was born May 1621. When he died i8 April 1623, she was left with the consolation of a child of yet undetermined sex in her womb. This fourth son was born in May. Naturally, the countess would consider "Rest" as the thing upon which she had set her hopes. Indeed, the earl and the countess needed to provide that "title" which would secure the Bridgewater name. To this particular family, Donne's admonition to "Arise and depart" was a warning tempered by the hope that the Ark might bear them (and their newborn son) safely to the Promised Land.

\section{THE "TITLE PROMIS'D THEM"}

In Llull's logic, promise and the possession are the "same" in that they represent antecedence and consequence. The ark-whether one call it "the booke of life, to shew them their Names" (188), or "Hierusalem" (215), or "home" (209)-represents that promise of possession, which 
Donne says cannot occur in this life. Because the opus is "God's proceeding at creation" (206), his creatures must bear patiently their role as patient, which is to die. Hence, "we were ripe for death at our birth" (2IO), and "desire to be dissolved" (2II).

First, Donne says, God "made all, and then digested, and then perfected them" (206). Therefore, he instructs, "Murmur not to admit the dissolution of body, and soul, upon your death-beds, nor the resolution, and putrefaction of the body alone in your graves, till God be pleased to repaire all, in a full consummation, and reuniting of body and soule in a blessed Resurrection" $(212-13)$. Some will understand these references alchemically, and these will also know that putrefaction anticipates the alchemical rainbow, which in turn, anticipates "home."

To the Bridgewater family, this rainbow represents the "Land of Promise" (186), particularly that "title promis'd them" (195). But how to get there remains the question, and Donne's instructions (Commonition) tell them how.

Frances Egerton, we have reason to believe, was poised to read her situation into these churching sermons, which were, after all, composed primarily for her. If she understood the alchemical level of Donne's discourse-that is, his references to "prison" (190 and 203), "Iron fornace" (190), and "Arke" (213) - then she was able to make the connection with the alchemical "wombe" (186, 215), also called the alembic. As a network of signs (prison, furnace, ark, and womb), all represent hope, even for "the title [that God] promis' $d$ " (195).

Poised against this (in the sense of Llull's Concordantia or Contrarietas) is the fact of the untimely deaths of the countess' sons. Alchemists called such failures, when the opus "failed to come to completion," abortion (Abraham 2). Certainly, she and her mother, the Countess Dowager of Derby (who may have attended this churching), knew first-hand that rest does not always come easy. ${ }^{4}$ Donne's sermons invite both women to redefine rest as a process, even in the alchemical sense whereby a "process of strife" resolves in peace (Abraham 141).

44 For a survey of the life of Lady Alice, Countess Dowager of Derby, see Parker, 2: 758-59. Lady Alice was the daughter of Sir John Spencer of Althorp. In 1579 she married Ferdinando Stanley (d. 1594), but failed to provide him with an heir. Consequently, she lost much of her property and became embroiled in a series of lawsuits with the new Earl of Derby, William Stanley. For information about this and other matters concerning her second marriage to the Lord Keeper, see Bald, who suggests that the motive behind Alice Spencer's orchestration of a marriage between her daughter Frances and the Lord Keeper's son John was to "safeguard her interests and those of her daughters. Egerton, on his side, became allied to some of the most powerful families in England" (no). The Countess Dowager of Derby lived uncil 1637, so it is reasonable to assume that she attended this churching. 
When Donne speaks of recovery after strife, he invites the countess to transfer Israel's dilemma to herself. As Israel looks for "a Messias" (188), so the countess, who already has eight daughters, looks for that "messiah" who will establish the Bridgewater name. Until he come, little Lady Alice, probably in the nursery during this churching service, will remain without a Protector, ${ }^{45}$ Surely the countess (and her mother) feared for this child and her sisters, as for herself, her husband, and the rest.

Donne examines reasons that Israel's birth is incomplete: "thy Navell was not cut, thou wast not washed, thou wast not salted" (186). Alchemical salt is associated with that mercury that purifies and "generates the Stone" (Abraham 120). The countess, of course, fears that this newborn, like the others, may remain "a loafe of Adams dow" (186), a failed opus. But Donne's instruction, the Commonition, suggests ways that the countess can prevent the alchemical abortion. Rather than a "false ascending," which is really a "cruell descending" (189), rather than "false joy and false ease" (190), Israel must understand that "perpetuall motions, and vicissitude" (193) are prerequisites to truc "Rest."

These references to Israel allow her to infer that her own works can assist the process, Medium, leading to Finis, even as the Jews have been exhorted to act: If "they had perform'd their part" (194) and "if they had kept the conditions" (196), Donne warns, they would not be without rest. Because they (and she) have "an ability, to performe the conditions" (197), and because God bids them (and her) "to doe something" (198), she knows that she is "able to doe something" (198) towards accomplishing her rest.

These challenges represent the newer Protestant concept of churching rites as occasions when women could act for themselves. For a moment, David Cressy says, women could cease to be passive "manmade instrument[s]" (199). Donne seems to have understood this new posture (not so new if one considers Llull's innate correlatives-agent, patient, act-which demand that every created being reflect the link between a good cause and a good effect). ${ }^{6}$ Donne's Commanition suggests that Frances Egerton should discover another verb. Rather than passive patient, she should assume the role of agent, acting on her own behalf.

Yes, God has given her the ability to come to His house, "having

45 See Parker, 2: 790-91. Alice Egerton was born in 1619. Parker lists her sisters as Lady Frances (b. 1604), Arbella (b. I605), Elizabeth (b. I606), Cecilia (I607-1626), Mary (b, 1609), Penelope (b, 1610), Katherine (b, 161t). Two dead sisters included Alice (16t3-14) and Anne (1618). 
rais'd her, from that Bed of weaknesse, to the ability of coming into his presence, here in his house" (198). And yes, she has brought her thank offering, as "Noab's sacrifice, after he came out of the Ark, is express'd, it is express'd thus, The Lord smelt a savor of Rest" (193). In this way, at least, she cooperates with God in accomplishing her own particular "Rest," which is her family's title secured.

\section{PRIMERO}

As a term particular to the culture of the time, "Rest" was also a reference to the then popular game of primero. When the rest, or the final stake, was lost, the game was up. Shakespeare and Milton alluded to primero in this way. 47 Charles I was said to eschew any "policie to play all his Rest at once, where hee might have lost more at one Game, than he had got in eight yeares." 48

Even this version of "Rest" would have had special meaning for political and religious factions yying for power. Buckingham's mismanagement of negotiations in Madrid, Sharpe reminds us, "made supporters of the match fear that the journey would disrupt years of delicate diplomacy" ("Arundel" 220). In July of 1623 , while the duke and the prince were abroad, the Earl of Arundel, whose alliance with Buckingham was beginning to disintegrate, was forced to leave England in order to attend to the death of his son in Flanders, a reminder of religious strife on another front ("Arundel" 220).

To the earl and countess, rest in the sense of primero represented the Bridgewater legacy. How each member of Donne's congregation understood Rest, therefore, was determined by what nouns and verbs were discovered and by how each matched "this" with "that."

${ }_{47}$ See, for example, Henry V: "Faith, I will live so long as I may, that's the certain of it; and when I cannot live any longer, I will do as I may: that is my rest" (2.2.14-16). Also Gascoigne's Supposes: A Comedie written in the Italian tongue by Ariosto, Englished by George Gascoyne of Grayes Inne. . . (1566): "This amorous cause that hageth in cotroversie betwene Domine doctor \& me, may be compared to that play at primero: of who some one peradveture shal leese a great sum of money before he win one stake, \& at last halfe in anger shal set up his rest: win it" (3.2. 1-5). [Text as represented by The Posies.] Also Milton's postscript to Animadversions upon the Remonstrant's Defence against Smectymnums (164) includes a reference to the game itself: "At that priméro of piety the Pope and Cardinals are the better gamesters, and will cogge a Die into heav'n before you" (174).

48 The citation (qtd. by OED) is from Richard Johnson's Kingdom and Commonwealth (1630). 


\section{REST}

$\wedge$

\section{ALCHEMICAL REST}

$\wedge$

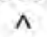

PRIMERO

POWER

SABBATH

To ADEPTS rest $=$ To GAMESTERS rest $=$

To JAMES I rest=

To THEOLOGIANS rest $=$

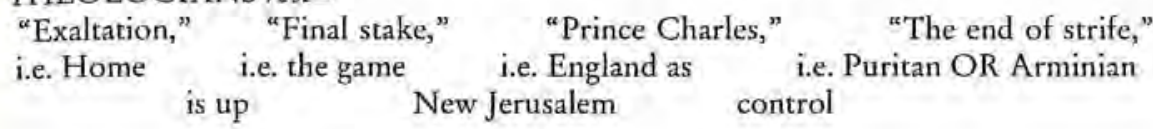

$\wedge \wedge$

$\wedge$

$\wedge$
A Living Heir
A Title
A Successful Match
The Synod of Dort/
(a successful
(a son to perpetuate
(an Anglo-Catholic
(the Arminian
Opus)
it)
alliance)
response)

$\wedge \wedge \wedge$

To the Wife To the Husband

To the Populace

To the Clergy

\section{$\wedge$ \\ $\wedge$ \\ $\wedge$ \\ BRIDGEWATER FAMILY \\ $\wedge$ \\ JAMES I \\ $\wedge$ \\ CALVINISTS/ARMINIANS \\ VARIOUS READING COMMUNITIES}

(DiAgram 2)

\section{PEACE AFTER STRIFE}

Donne ends "Sermon 10 " with references to the churching service in The Book of Common Prayer. His revision of the prescribed text is interesting in that it expands rather than delimits meaning. "The Churching of Women" ceremony indicates that Psalm 127 be read: "Except the Lord build the house: their labour is but lost that build it....It is but lost labour that ye haste to rise up early, and so late take rest" (399-400). As we have seen, Donne has developed this part of the text throughout both sermons, defining "rest" in terms of "un-rest."

The Psalm continues:

Lo, children and the fruit of the womb: are an heritage and gift that cometh of the Lord. Like as the arrows in the hand of the giant: even so are the young children. Happy is the man that hath his quiver full of them (400). 
Although the psalmist speaks of arrows (in the plural), Donne changes the text so that it reads a single arrow: "here there be not our Rest; for he that shoots an arrow at a mark, yet means to put that arrow into his Quiver again" (2I5). By changing the text, Donne changes the original meaning of "many children" to "tribulation" and "death," even as he defines it elsewhere:

Wee finde many mentions in the Scriptures of filling of quivers, and emprying of quivers, and arrows, and arrows, still in the plurall, many arrows. But in all the Bible, I think, we finde not this word, (as it signifies tentation, or tribulation) in the singular, one arrow...The arrow that flies by day....that one arrow common to all, that day-arrow visible to all, is the naturall death...The arrow of death (Sermons $2: 6 \mathrm{t}$ ).

The archery motif, both in the prescribed service and in Donne's revision of it, is meant to include both husband and wife. Donne takes advantage of this opportunity to include the Earl of Bridgewater, his life-long friend, 49 inviting both husband and wife to ponder this arrow.

As in the rest of primero, the stakes are high, but if this couple can emulate God, who knows how to convert straight lines into circles, then things lost, like arrows and sons, can be retrieved. If they aim this newborn into the path of his brothers (which is down), they can somehow retrieve them all, bringing them $u p$ "into his Quiver again" (215). With this analogy Donne invites both husband and wife to exercise faith. Be content, he says, "to depart into the wombe of the Earth, our grave" (215). God, who lays our bodies in the grave, only does this so that he can "glorifie them.... at the last day" (215).

This admonition brings together many references to death scattered throughout the sermon(s)-to dissolution (209, 211, 212), putrefaction (203, 2II, 212-13), to "[male] corruption" (186), to "the [female] worm" (186), and to other "wormes" (187 and 212). Although we today may think it strange to emphasize such things in a churching, there is reason to believe that Donne's congregation was able to reinvent the signs. Many recognized the alchemical counterpart, which Abraham defines as, "the mercurial waters of life and death, the transforming arcanum, the secret fire,... [It is] both the devouring worm of death consuming all corruption and the nourishing worm of life which feeds the alchemical chick" (220).

49 For Donne's relations with the Egerton brothers, see R. C. Bald (above), John Egerton was Donne's junior by seven years. He and his older brother Thomas first met Donne at Lincoln's Inn in the early 1590s. Later, through the offices of the Egerton brothers, Donne became secretary to their father, the Lord Keeper of the Great Seal (1596). 


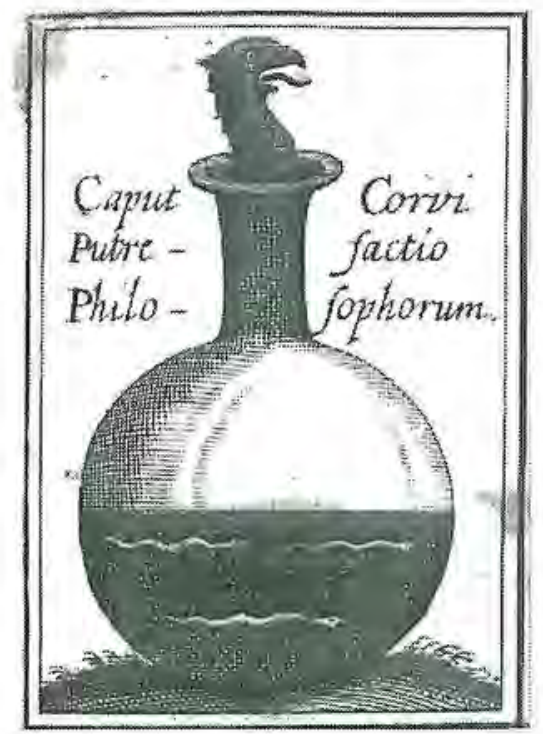

Figure 2: "Mercurial WORMS IN ALEMbiC." WOODCUT ILLUSTRATION FOR JOANNES DANIELMYLIUS, ANATOMIA AURI SIVE TYROCINIUM MEDICO-CHYMICUM (1628). BODLEIAN, $4 \mathrm{~S}_{5} \mathrm{MED}(3)$.

Frances Egerton and her two sisters, who may have attended, 50 would have recognized Donne's compliment when he designated the "Mother, and...sister" worm as that nourishing worm that feeds the chick, as opposed to the "father" worm of corruption that destroys (186). Many, including millenarians, would have recognized these worms as representations of Llull's religious and cultural unity, ${ }^{51}$ or divine love, symbolized by the red triangle. Many, including millenarians, would have understood these worms as affirmation of "unrest" but also as affirmation of rest "at the last day," the last four words they hear.

50 Frances Egerton's two sisters were Lady Elizabeth (married to Henry Hastings in 1603) and Lady Anne, whose first husband died in 1621. For her unfortunate second marriage, see Parker, 759 .

sI For discussion of worms in Donne's sermons, see Michael L. Hall, pp. 201-214. He observes, Donne joins all creatures, gnats and archangels, worms and cedars, not in a great chain of being or hierarchy of creatures, but in a circle or continuum. All are equally representative of the creator ${ }^{n}$ (206). Although he does not say so, this is a comment on Llull's spiritual logic, as well as hermeticism. 
Were it the case that Donne delivered this sermon in 1621 , then he was preparing Frances Egerton for her son's death in April I623. When he warns her, "Here is not your Rest...that Rest, that Peace, that Quiet which they had propos'd, and imagin'd to themselves" (193), he may have unwittingly offered a memento mori to be kept in the Bridgewater library for future generations to read and ponder.

If, on the other hand, these sermons were preached in 1623 , then Donne's Consolation was prophetic. For in 1623 the Countess of Bridgewater gave birth to a son who grew up to play the role of the Elder Brother in Milton's Comus, And four-year-old Alice grew up to play the role of Milton's Lady. Now, thanks to Milton, her brother forever protects her, establishing throughout the ages the Bridgewater name. Those who visit Ludlow Castle today will find only ruins of the hall where the masque was performed. But mere accident of time is eclipsed by the fact that Comus endures, that centuries after Milton composed it, various reading communities continue to find themselves in it. To the Bridgewaters the rainbow has come full circle. This is true "Rest." This is gold.

ROBERTA ALBRECHT INDEPENDENT SCHOLAR

\section{WORKS CITED}

Abraham, Lyndy. Dictionary of Alchemical Imagery. New York: Cambridge UP, 1999.

AlBRECHT, Roberta. The Virgin Mary as Alchemical and Lullian Reference in Donne. Susquehanna UP, 2005.

BALD, R. C. John Donne: A Life. Oxford: Clarendon, 1970.

Calvin, John. Institutes of the Christian Religion. Ed. John T. Mc Neill. Trans. Ford Lewis Battles. Vol. 20. The Library of Christian Classics. Philadelphia: Westminster, 1960.

CARRUTHERS, Mary. The Book of Memory: A Study of Memory in Medieval Culture. New York: Cambridge UP, 1998.

Chamberlin, John S. Increase and Multiply: Arts-of-Discourse Procedure in the Preaching of Donne. Chapel Hill: U of North Carolina P, 1976.

Church of England. Book of Common Prayer: 1662 Version. Oxford: Oxford UP, 1969.

CluCAS, Stephen. "Translator's Introduction." Logic and the Art of Memory: The Quest for a Universal Language by Paulo Rossi. viixiv. Chicago: U of Chicago P, 2000.

Crawshaw, Eluned. "Hermetic Elements in Donne's Poetic Vision." 
John Donne: Essays in Celebration. Ed. A. J. Smith. 324-48. London: Methuen, 1972.

CRESSY, David. Birth, Marriage and Death: Ritual, Religion, and the Life-Cycle in Tudor and Stuart England. New York: Oxford UP, 1997.

DIEHL, Huston. "Discovering the Old World: The Renaissance Emblem Book as Cultural Artifact." Approaches to Teaching the Metaphysical Poets, edited by Sidney Gottlieb, 68-74. New York: Modern Language Association of America, 1990.

DonNE, John. Essays in Divinity. Ed. Evelyn M. Simpson. Oxford: Clarendon, 1952.

The Sermons of John Donne. Ed. George R. Potter and Evelyn M. Simpson. Vol. 5 Berkeley: U of California P, 1953-62.

Duran, Manuel. "Ramon Llull: An Introduction." Catalan Review 4.1-2 (July-December 1990): n-29.

FLYNN, Dennis. "Awry and Squint': The Dating of Donne's Holy Sonnets." John Donne Joumal 7 (1988): 35-46.

HACKEL, Heidi Brayman. "Boasting of Silence": Women Readers in a Patriarchal State." Reading, Society and Politics in Early Modern England. Ed. Kevin Sharpe and Steven N. Zwicker. New York: Cambridge UP, 2003. 10I-121

Hall, Michael L. Hall. "Circles and Circumvention in Donne's Sermons." Journal of English and Germanic Philology 82.2 (April I983): $20 \mathrm{I}-2 \mathrm{I}_{4}$.

Hotson, Howard. Paradise Postponed: Johann Heinrich and the Birth of Calvinist Millenarianism. Boston: Kluwer, 2000.

JoHnson, Jeffrey. The Theology of John Donne. Rochester, NY: D.S. Brewer, 1999.

JOHNSTON, Mark D. The Spiritual Logic of Ramon Llull. Oxford: Clarendon, 1987.

KATZ, David S. Philo-Semitism and the Readmission of the Jews to England, 1603-1655. Oxford: Clarendon, 1982.

- "The Prehistoric English Bible." Judaeo-Christian Intellectual Culture in the Seventeenth Century. Ed. Allison P. Coudert, et al., 71-90. Boston: Kluwer, 1999.

KeLLY, Edward. The Englishman's Two Excellent Treatises on the Philosopher's Stone. 1676. Trans. Arthur Edward Waite (1893). London: Stuart and Watkins, 1970.

KeYNES, Geoffrey. A Bibliography of Dr. John Donne: Dean of Saint Paul's. $4^{\text {th }}$ ed. Oxford: Clarendon, 1973.

KNIGHTON, C. S. "The Lord of Jerusalem: John Williams as Dean of Westminster." Westminster Abbey Reformed. Eds. C. S. Knighton and Richard Mortimer, 232-60. Burlington, VT: Ashgate, 2003.

LINDEN, Stanton J. "Expounding George Ripley: A Huntington 
Alchemical Manuscript." Huntington Library Quarterly 6r.3-4 (2000): II-28.

- The Mirror of Alchimy Composed by the Thrice-Famous and Learned Fryer, Roger Bachon. New York: Garland, 1992.

Llull, Ramon. Selected Works of Ramon Llull (1232-1316). Ed. and Trans. Anthony Bonner. Princeton, New Jersey: Princeton UP, 1985.

LUTHER, Martin. The Table Talk of Martin Luther. Trans. and Ed. William Hazlitt. London: Bell and Daldy, 1872.

Matar, N. I. "The Date of John Donne's Sermon 'Preached at the Churching of the Countess of Bridgewater." Notes and Queries 39 (1992): $447-48$.

MAZzeO, Joseph A. "Notes on John Donne's Alchemical Imagery." Isis 48 (June 1957): 103-23.

Mitron, Anthony. "Canon Fire: Peter Heylyn at Westminster." Westminster Abby Reformed 1540-1640. Ed. C.S. Knighton and Richard Mortimer. 207-31. Burlington, Vermont: Ashgate, 2003.

- "The Creation of Laudianism; A New Approach." Politics, Religion and Popularity in Early Stuart Britain: Essays in Honour of Conrad Russell. Ed. Thomas Cogswell, Richard Cust and Peter Lake. 162-84. New York: Cambridge UP, 2002.

MitTon, John. Animadversions upon the Remonstrants Defence, against Smectymnuus. Ed. Harry Morgan Ayres. The Works of John Milton. Vol. 3.r. New York: Columbia UP, 1931. 105-180.

PARKER, William Riley, Milton: A Biography, 2 vols. Oxford: Clarendon, 1968 .

Pereira, Michela. The Alchemical Corpus Attributed to Raymond Lull. Warburg Institute Surveys and Texts. London: Warburg Institute, 1989 .

PREST, Wilfred R. "The Art of Law and the Law of God: Sir Henry Finch (1558-1625)." Puritans and Revolutionaries: Essays in Seventeenth-Century History. Eds. Donald Pennington and Keith Thomas, 94-117. Oxford: Clarendon, 1978.

ROBERTS, Gareth. The Mirror of Alchemy: Alchemical Ideas and Images in Manuscripts and Books from Antiquity to the Seventeenth Century. Toronto: U of Toronto P, 1994.

ROBERTS, Julian and Andrew G. Watson. John Dee's Library Catalogue. London: The Bibliographical Society, 1990.

Rossi, Paulo. Logic and the Art of Memory: The Quest for a Universal. Language. Trans. and Intro. Stephen Clucas. Chicago: U of Chicago $\mathrm{P}, 2000$.

SCHMIDT-BIgGEMANN. Topica Universalis: Eine Modellgeschichte Humanistischer und Barocker Wissenschaft. Hamburg: Meiner, 1983. 
Sharpe, Kevin. "The Earl of Arundel, His Circle and the Opposition to the Duke of Buckingham, 1618-1628." Faction and Parliament: Essays on Early Stuart History. Ed. Kevin Sharpe, 209-44. New York: Oxford UP, i978.

"Introduction: Discovering the Renaissance Reader." Reading, Society and Politics in Early Modern England. Eds. Kevin Sharpe and Steven N. Zwicker. I-37. New York: Cambridge UP, 2003.

- Sir Robert Cotton, I586-I63L. History and Politics in Early Modern England. New York: Oxford UP, 1979.

SHAWCROSS, John T. Intentionality and the New Traditionalism: Some Liminal Means of Literary Revisionism. University Park: Pennsylvania State UP, 199I.

Stone, Gregory B. "Ramon Llull vs. Petrus Alfonsi: Postmodern Liberalism and the Six Liberal Arts." Medieval Encounters: Jewish, Christian and Muslim Culture 3.I (March 1997): 70-93.

StURLESE, Rita M. Bibliografia, Censimento. Firenze: Olschki, 1987.

Summers, Joseph H. George Herbert: His Religion and Art. 1954. Cambridge: Harvard UP, 1968.

VANCE, Norman. Irish Literature: A Social History: Tradition, Identity and Difference. Ed. Norman Vance. Oxford: Blackwell, 1990.

YATES, Frances. The Art of Memory. Chicago: U of Chicago P, 1966.

- Giordano Bruno and the Hermetic Tradition. Chicago: U of Chicago P, 1964.

ZWICKER, Stephen N. "Introduction: Discovering the Renaissance Reader." Reading, Society and Politics in Early Modern England. Eds. Kevin Sharpe and Steven N. Zwicker. 1-37. New York: Cambridge UP, 2003. 